\title{
Muhasebe Meslek Mensuplarının Muhasebe Uygulamalarındaki E-Dönüşüm Sürecine Illişkin Görüş ve Beklentileri: Hatay İli Örneği
}

\author{
Opinions and Expectations of Professional Accountants Regarding the E- \\ Transformation Process in Accounting Practices: Sample of Hatay Province
}

\author{
Fatmanur DENIZ * \\ Şükran GÜNGÖR TANÇ **
}

\begin{abstract}
$\ddot{O} Z$
Bilişim teknolojilerinde yaşanan hızlı değişim ve gelişmeler ile birlikte kamu ve özel işsletmeler tarafindan yürütülen finansal süreçlerin kontrolü elektronik ortamda yapılmaya başlanmıştır. Bu gelişmeler, finansal süreçlerin kontrolünde büyük öneme sahip olan muhasebe sistem ve uygulamalarına elektronik dönüşüm (e-dönüşüm) olarak yansımıştır. Bu çalıșmanın temel amacl, elektronik uygulamaların en aktif kullanıcısı olan muhasebe meslek mensuplarının muhasebe uygulamalarında yaşanan e-dönüşüm süreci hakkindaki görüşlerini ve beklentilerini belirlemektir. Bu amaca uygun olarak düzenlenmiş anket formları Hatay SMMO (Serbest Muhasebeci Mali Müşavirler Odast)'ya kayttl muhasebe meslek mensuplarına uygulanmış ve sonuçlar SPSS (Statistical Package for the Social Sciences) paket programı ile analiz edilmiştir. Yapılan analiz sonucunda muhasebede e-dönüşüm ile ilgili en fazla sorun olarak algllanan konu, müsteri işletmelerin dijital muhasebeye ilişkin bilgi düzeylerinin ve teknolojik altyapılarının yetersizliği olmuştur.
\end{abstract}

\author{
ANAHTAR KELIMELER \\ Bilgi Teknolojileri, E-Dönüşüm, Muhasebe. \\ JEL KODLARI \\ O14, M49, M40.
}

\begin{abstract}
With the rapid changes and developments in information technologies, the control of financial processes carried out by public and private enterprises started to be carried out electronically. These developments have been reflected as electronic transformation (e-transformation) in accounting systems and applications, which are of great importance in controlling financial processes. The main purpose of this study is to determine the views and expectations of professional accountants, who are the most active users of electronic applications, about the e-transformation process experienced in accounting practices. The questionnaire forms prepared in accordance with this purpose were applied to the professional accountants registered in Hatay SMMO (Chamber of Independent Accountants and Financial Advisors). The results were analyzed with the SPSS (Statistical Package for the Social Sciences) package program. As a result of the analysis, the main finding is that lack of knowledge level and technological infrastructure of the client enterprise regarding etransformation has been the most reported issue.
\end{abstract}

KEYWORDS
Information Technologies, E-transformation, Accounting
JEL CODES
O14, M49, M40.

\begin{tabular}{|c|c|c|}
\hline \multicolumn{2}{|r|}{$\begin{array}{c}\text { Makale Gelis Tarihi / Submission Date } \\
02.10 .2020\end{array}$} & $\begin{array}{c}\text { Makale Kabul Tarihi / Date of Acceptance } \\
15.10 .2020\end{array}$ \\
\hline Atıf & $\begin{array}{l}\text { Deniz, F. ve Güngör Tanç, Ş. (2020). } \\
\text { Sürecine İlişkin Görüş ve Beklentileri } \\
\text { Dergisi, } 23 \text { (2), 622-636. }\end{array}$ & $\begin{array}{l}\text { suplarının Muhasebe Uygulamalarındaki E-Dönüşüm } \\
\text { çu Üniversitesi Sosyal Bilimler Meslek Yüksekokulu }\end{array}$ \\
\hline
\end{tabular}

\footnotetext{
* Arş. Gör., Nevşehir Hacı Bektaş Veli Üniversitesi, İktisadi ve İdari Bilimler Fakültesi, fdeniz@nevsehir.edu.tr, ORCID: 0000-0002-4291-8026

*** Doç. Dr., Nevşehir Hacı Bektaş Veli Üniversitesi, İktisadi ve İdari Bilimler Fakültesi, sgungor@ nevsehir.edu.tr, ORCID: 0000-0002-0675-2479
} 


\section{GİRIŞ}

Bilgi ve iletişim teknolojilerinde yaşanan gelişmeler ile birlikte dijitalleşen dünyada yaşamın tüm alanlarında olduğu gibi muhasebe ve finans alanında da köklü değişimler yaşanmasına neden olmuştur. Dijitalleşen çağ olarak ifade edilen bu dönemde muhasebe ve uygulamaları da dijitalleşerek, elektronik uygulamaların kullanımı giderek yaygınlaşmaya başlamıştır.

Türkiye'de elektronik dönüşüm süreci e-devlet projesi ile başlamıştır. Bu proje kapsamında yer alan uygulamalardan birisi 1998 yılında Maliye Bakanlığı'nın bağlı kuruluşu olan GỉB (Gelir İdaresi Başkanlığı) tarafından hayata geçirilen Vergi Dairesi Otomasyon Projesi (VEDOP)'dir. VEDOP projesi, vergi dairesinde yapılan tüm işlemlerin bilgisayarla yapılabilir hale getirerek; iş yükünü azaltmayı, personellerin motivasyonunu ve verimliliğini arttırmayı, bilgisayarlar aracılığıyla elde edilen veri ve bilgilerden güvenilir bir karar, destek ve yönetim bilgi sisteminin oluşturulması amaçlanmıştır (Kibar Bilginli, 2011: 174-175). Proje kapsamında geliştirilen e-fatura, e-defter, e-beyanname, e-arşiv ve e-tebligat gibi e-belge sistemleri ile muhasebede e-dönüşüm başlamıştır.

Muhasebe alanında yaşanan e-dönüşüm sürecinin getirdiği yenilikler, mesleğin gerektirdiği işlerin yürütülmesini oldukça kolaylaştırmış ve meslek mensuplarının verimliliği bu uygulamalar ile artmıştır. Gelişen elektronik uygulamalar muhasebe meslek mensupları başta olmak üzere işletmeler, kamu kurum ve kuruluşları, TÜRMOB (Türkiye Serbest Muhasebeci Mali Müşavirler ve Yeminli Mali Müşavirler Odaları Birliği) olarak sıralanabilecek tüm muhasebe paydaşlarına oldukça önemli zaman ve maliyet avantajı sağlamaktadır. Ayrıca bu yenilikler ile birlikte muhasebe meslek mensuplarının geleneksel rolü de değişmeye başlamış olup artık muhasebe meslek mensuplarının asıl rolü, kayıt tutmak ya da arşivlemekten daha çok geliştirilen teknolojik uygulamaları kullanarak analiz yapmak ve faydalı bilgiler sunmaktır. Bu kapsamda muhasebe meslek mensuplarının muhasebede yaşanan e-dönüşüm hakkındaki beklenti ve görüşleri oldukça önem kazanmıştır.

Çalışma kapsamında ilk olarak muhasebede e-dönüşüm ve elektronik belge uygulamaları ile ilgili açıklamalara yer verilmiştir. Muhasebe uygulamalarında yaşanan e - dönüşüm süreci konusunu ele alan çalışmalara literatür taraması başlığı altında yer verilmiştir. Çalışmanın uygulama kısmında ise Hatay ilinde faaliyet gösteren muhasebe meslek mensuplarının muhasebe uygulamalarında yaşanan e-dönüşüm hakkındaki görüşlerini ve beklentilerini belirlemek amacıyla bir anket çalışması gerçekleştirilmiştir. Anketlerden elde edilen verilerin analizi sonucunda, muhasebe meslek mensuplarının bilgi düzeylerinin e-dönüşüm uygulamaları hakkındaki görüşleri üzerinde pozitif yönde ve anlamlı bir etkisi olduğu tespit edilmiş̧ir. Buna ek olarak muhasebe meslek mensuplarının müşteri işletmeleri, kamu kurumlarını ve mesleki kuruluşları dijital dönüşüm kapsamında değerlendirmeleri sonuçları ile e-dönüşüm hakkındaki görüşleri arasında aynı yönde ve anlamlı bir ilişki tespit edilmiştir. Tespit edilen sonuçlar çevresinde konu ile ilgili yorum ve öneriler çalışmanın sonuç kısmında sunulmuştur.

\section{MUHASEBEDE E-DÖNÜŞÜM}

Elektronik dönüşüm, bilgi ve iletişim teknolojilerinin verimli bir şekilde kullanılarak; bir kurumun kültürünün, iş modelinin, organizasyon yapısının, iş süreçlerinin, ürün ve hizmetlerinin tüm paydaşlarının yararını göz önünde bulundurarak, bir bütünlük ve denge içerisinde değiştirilmesi sürecidir (Arıkan, 2015: 5).

Türkiye'de e-dönüşüm uygulamalarının başlaması ile birç̧ok yeniliği beraberinde getirmiştir. E-dönüşümün ilk adımı, her vatandaşın bir kimlik numarası ile takibinin esas alındığı, nüfus ve vatandaşlık işlemlerinin merkezi ortak bir internet sistemi üzerinden gerçekleştirilmeye başlandığı MERNIS (Merkezi Nüfus İdaresi Sistemi) projesidir. Daha sonra e-imza uygulaması ile sslak imza kullanmaya gerek kalmaksızın zaman ve para tasarrufu sağlanmıştır. Sinema işletmeleri ve yolcu taşımacılığı yapan firmaların e-bilet uygulaması kapsamına alınması, SGK ve vergi dairelerine gönderilen beyanname ve bilgilerin dijital ortamda gönderilmeye başlanması, bankaların müşterilerine kredi kartı veya hesap ekstralarını yazılı olarak değil e-posta yolu ile iletmeleri dijitalleşme sürecinde yaşanan yeniliklere örnek olarak verilebilir.

E-dönüşüm ile birlikte muhasebe alanında yeni bir kavram oluşmuş ve e-muhasebe olarak adlandırılmıştır. E-muhasebe, kuruluşlarda finansal verileri yakalamak ve işlemek için bilgisayar teknolojisine dayanan herhangi bir muhasebe sistemini tanımlamak için kullanılan bir terim olan elektronik muhasebe anlamına gelir (Amidu, Effah \& Abor, 2011: 146).

E-dönüşüm sürecinde uygulamaya başlanan GIB internet sitesinde e-işlemler sekmesinde yer alan uygulamalar şu şekilde sıralanabilir: İnteraktif vergi dairesi, internet vergi dairesi, defter-beyan sistemi, ebeyanname, borç sorgulama ve ödeme, hazır beyan sistemi, e-belge (e-fatura, e-irsaliye, e-arşiv, e-SMM, emüstahsil makbuzu, e-bilet), e-defter, e-tebligat, B-trans (elektronik bilgi transferi), iadem nerede? (KDV ve 
Gelir/Kurumlar Vergisi iade süreçlerinin takip edilmesi amaciyla oluşturulmuştur), e-yoklama fişi görüntüleme (GİB, 2020).

\section{ELEKTRONIK BELGE UYGULAMALARI}

Teknoloji alanında yaşanan değişim ve gelişimler sonucunda dünyada ve ülkemizde büyük değişimler yaşanmıştır. Yaşamın tüm alanlarında etkili olan bu durum beraberinde yeni uygulamalar doğurmuştur. $\mathrm{Bu}$ gelişmeler, elektronik belge kavramını hayatımıza eklemiş, kurumlarda elektronik belge, elektronik belge yönetimi önem kazanmıştır (Ermiş, 2006: 140).

E-Belge, tüm mal ve hizmet alımları ile giderlerinin elektronik ortamda belgelenmesidir (Ay, 2006: 71). Başka bir tanımı ise 5 Mart 2010 tarihinde Maliye Bakanlığı tarafından yayınlanan 397 sıra No'lu tebliğinde ise "şekil hükümlerinden bağımsız olarak Vergi Usul Kanununa göre düzenlenmesi zorunlu olan belgelerde yer alan bilgileri içeren elektronik kayıtlar bütünü” şeklindedir (397 No’lu VUK Genel Tebliği, 2010).

E-belge başlığı altında sırasıyla e-fatura, e-irsaliye, e-arşiv, e-SMM, e-müstahsil makbuzu, e-bilet uygulamalarına yer verilecektir.

\subsection{Elektronik Fatura (e-fatura)}

E-fatura, elektronik ortamda oluşturulur, saklanır ve ibraz edilir, değişmezliğini sağlamak için mali mühürle imzalanır. E-fatura, kâğıt fatura ile aynı nitelikleri ve hukuki özellikleri taşımaktadır. (Gülten, 2018: 58).

Türkiye'de e-fatura uygulaması 397 Sıra No'lu Vergi Usul Kanunu Genel Tebliği ile birlikte kullanımına sunulmuş olup ve 5 Mart 2010 tarihinden beri ilgilileri tarafından kullanılmaktadır. E-fatura uygulamasının amac1 "Gelir İdaresi Başkanlığı tarafından yönetilen ve tek formatta olan belli bir standarda dayanan satıcı ve alıcı arasında güvenli, zaman ve maliyet tasarrufu sağlayan bir sistem oluşturmaktır" şeklinde belirlenmiştir (GİB, 2020a).

E-fatura kayıtlı kullanıcılar ifadesi "397 Sıra No'lu Vergi Usul Kanunu Genel Tebliği ile getirilen e-fatura uygulamasına, Mali Mühür Sertifika temin işlemlerini tamamlayarak dâhil olan kullanıcılardır” şeklinde tanımlanmıştır. Ağustos 2020 itibariyle 294402 adet kullanıcı e-fatura uygulamasını kullanmaktadır. (GİB, 2020b)

\subsection{Elektronik İrsaliye (e-irsaliye)}

E-irsaliye uygulaması "kâğıt ortamda düzenlenmekte olan sevk irsaliyesinin elektronik ortamda düzenlenmesi, elektronik ortamda iletilmesi, muhafaza ve ibraz edilmesine ilişkin düzenlemeleri kapsayan uygulamadır" şeklinde tanımlanmaktadır. 509 Sıra No'lu Vergi Usul Kanunu Genel Tebliği ile belirli sektör ve mükellef grupları e-irsaliye uygulamasına geçiş yapma konusunda zorunlu kılınmıştır. E-irsaliye uygulaması ile mal hareketlerinin elektronik ortamda izlenebilmesi amaçlanmıştır (GİB, 2020c). Ağustos 2020 tarihi itibariyle 77754 adet kullanıcı e-irsaliye uygulamasını kullanmaktadır (GİB, 2020d).

\subsection{Elektronik Arşiv (e-arşiv)}

30 Aralık 2013 tarihli 433 sıra No'lu Resmi Gazete'de yayınlanan Vergi Usul Kanunu Genel Tebliği'ne göre; "e-arşiv, elektronik ortamda oluşturulan faturanın elektronik ortamda muhafaza ve ibraz edilmesi olarak e-arşiv uygulaması ise Başkanlık tarafından belirlenen standartlara uygun olarak faturanın elektronik ortamda oluşturulması, elektronik ortamda muhafazası, ibrazı ve raporlamasını kapsayan uygulama" olarak tanımlanmıştır (433 No'lu VUK Genel Tebliği, 2013).

Vergi mükelleflerinin kullanmış oldukları belge ve evrakların 5 ila 10 yıl arasında saklanma zorunluluğu vardır. Bu belgelerin uzun süreler sağlıklı bir şekilde saklanması, birçok kurum için çoğu zaman kolay olmamaktadır. E-arşiv dönüşümüyle birlikte artık kıymetli evraklar ve arşiv niteliğinde olan belgeler, daha kolay bir şekilde saklanabilmektedir. Riskleri daha az olması ve yer tasarrufundan dolayı ilgili kurumlar tarafindan ilgi görmektedir (Karaer, 2019: 4361).

Ağustos 2020 tarihi itibariyle e-arşiv fatura uygulaması kullanılarak e-fatura düzenleyen mükelleflerin say1s1 277961 adettir (Gï, 2020e).

\subsection{Elektronik Serbest Meslek Makbuzu (e-SMM)}

Serbest meslek erbabı, mesleki faaliyetlerine ilişkin her türlü tahsilatı için iki nüsha serbest meslek makbuzu tanzim etmek ve bir nüshasını müşteriye vermek, müşteri de bu makbuzu istemek ve almak mecburiyetindedir (213 No'lu VUK Genel Tebliği, 1961).

E-SMM uygulaması, 509 Sira No'lu Vergi Usul Kanunu Genel Tebliği ile “e-Serbest Meslek Makbuzunun (e-SMM) elektronik ortamda oluşturulması, muhatabının talebi doğrultusunda kâğıt veya elektronik ortamda

Selçuk Üniversitesi Sosyal Bilimler Meslek Yüksekokulu Dergisi, Yıl: 2020 Cilt: 23 Sayı:2 
iletilmesi, elektronik ortamda muhafaza ve ibraz edilebilmesi ve Başkanlığa elektronik ortamda iletilebilmesi veya raporlanabilmesine ilişkin usul ve esasları kapsayan uygulama" şeklinde tanımlanmıştır (GIB, 2020f). ESMM, kâğıt serbest meslek makbuzu ile aynı hukuki özelliklere sahip olan bir belgedir (Gülten, 2018: 110). Ağustos 2020 tarihi itibariyle e-SMM Kayıtlı Kullanıcılar Listesi'nde 183785 adet kullanıcı bulunmaktadır (Gï, 2020g).

\subsection{Elektronik Müstahsil Makbuzu (e-MM)}

213 No’lu VUK Genel Tebliği’ne göre elektronik müstahsil makbuzuna dair tanımlamalar şu şekildedir: "Birinci ve ikinci sınıf tüccarlar ile kazancı basit usulde tespit edilenler ve defter tutmak mecburiyetinde olan çiftçiler gerçek usulde vergiye tabi olmayan çiftçilerden satın aldıkları malların bedelini ödedikleri sırada iki nüsha makbuz tanzim etmeye ve bunlardan birini imzalayarak satıcı çiftçiye vermeye ve diğerini ona imzalatarak almaya mecburdurlar. Müstahsil makbuzunun tüccar veya alıcı çiftçi nezdinde kalan nüshası fatura yerine geçer" (213 No'lu VUK Genel Tebliği, 1961).

E-MM uygulaması, 509 Sira No'lu Vergi Usul Kanunu Genel Tebliği ile "hâlihazırda kâğıt ortamda düzenlenmekte olan müstahsil makbuzunun, elektronik belge olarak düzenlenmesi ile kâğıt ve elektronik ortamda muhafaza ve ibraz edilmesi ve Başkanlığa elektronik ortamda iletilmesine veya raporlanabilmesine ilişkin usul ve esasları kapsayan uygulama" olarak tanımlanmıştır (GİB, 2020h). Ağustos 2020 tarihi itibariyle e-Müstahsil Kayıtlı Kullanıcılar Listesi'nde 23689 adet kullanıcı bulunmaktadır (GİB, 20201).

\subsection{Elektronik Bilet (e-bilet)}

509 Sira No'lu Vergi Usul Kanunu Genel Tebliği'nde e-bilet uygulamasına dair "kâğıt ortamda düzenlenmekte olan biletler (kara, deniz ve hava yolu yolcu biletleri ile sinema, tiyatro, spor müsabakası vb. etkinliklere ait biletler gibi) ile yolcu listelerinin elektronik ortamda düzenlenebilmesi, muhatabın talebi doğrultusunda elektronik ortamda veya kâğıt olarak iletilebilmesi ve Başkanlığa elektronik ortamda iletilmesine ve raporlanabilmesine ilişkin yapılan düzenlemeler" açıklaması yer almaktadır (GİB, 2020i). Ağustos 2020 tarihi itibariyle e-bilet/yolcu listesi düzenleme izni alan mükellefler listesi’nde 135 adet kullanıc1 bulunmaktadır (GIB, 2020j).

\section{LITERATÜR TARAMASI}

Aşağıda muhasebe uygulamalarında yaşanan e - dönüşüm sürecini çeşitli açılardan ele alan ulusal ve uluslararası birtakım çalışmanın bulgularına yer verilmiştir.

Amidu vd. (2011) tarafından yapılan bu çalışma Gana'daki KOBİ'ler arasındaki e-muhasebe uygulamalarını araştırmak ve e-muhasebenin muhasebe meslek personelleri tarafından benimsenmesi için beklentileri, gerçekleri ve engelleri incelemek amacıyla gerçekleştirilmiştir. Araştırma tasarımı, ülke çapında sistematik olarak seçilmiş bir KOBİ örneği kullanan bir anket metodolojisine dayanmaktadır. Bulgular, KOBİ'lerin finansal bilgilerini oluşturmak için e-muhasebe yazılımlarını kullanmaya başladıklarını göstermektedir.

Noronda ve Kulkarni (2012) Hindistan' da çalışan muhasebe meslek mensuplarının e-muhasebe hakkındaki görüşlerini belirlemek amacı ve Hindistan'da bu konuda bir çalışma olmaması gerekçesiyle gerçekleştirdikleri çalışmada 40 yeminli muhasebeciye geliştirdikleri anket formunu yüz yüze görüşme yöntemi ile uygulamışlardır. Tanımlayıcı istatistikler çıkarılarak sunulan bulgulara göre, e-muhasebe her şeyden önce muhasebe profesyonelleri için yeni firsatlar sunmaktadır. Fakat oluşan yeni çalışma ortamı; çalışanların bilgi eksikliği ve şirketlerin e-muhasebeyi benimsememesinden dolayı oldukça zor bir şekilde oluşturulmaktadır. Bu nedenle Hindistan'da söz konusu işlemler için birtakım standartların geliştirilerek uygulamaya konulması gerektiği ifade edilmiştir.

Relhan (2013) tarafindan gerçekleştirilen çalışmada, e-muhasebeyi benimseyen küçük ve orta ölçekli muhasebe şirketlerini etkileyen faktörlerin ve e-muhasebenin bu şirketlere etkilerinin belirlenmesi amaçlanmıştır. Bu kapsamda Iacovou vd. (1995) tarafından elektronik veri değişiminin benimsenmesi ve küçük işletmelerin bilgi teknolojilerini kullanmasına dair algılarının ölçülmesini sağlayan; algılanan faydalar, örgütsel hazır olma, güven ve dış baskı olmak üzere dört faktör içeren model kullanılmıştır.

Velankar vd. (2013) Hindistan'ın Madhya Pradesh eyaletinde faaliyet gösteren KOBİ'ler arasındaki emuhasebe uygulamalarını araştırmıştır. Çalışmada aynı zamanda e-muhasebenin benimsenmesindeki beklentileri, gerçekleri ve engelleri incelemiştir. Araştırma tasarımı, eyalet çapında sistematik olarak seçilmiş bir KOBİ örneği kullanan bir anket metodolojisine dayanmaktadır. Bulgular, KOBİ'lerin finansal bilgilerini üretmek için muhasebe yazılımları kullandıklarını ortaya koymaktadır.

Abed (2014) tarafından yapılan çalışmada, muhasebe çalışma planında verilen e-iş eğitiminin düzeyini ve içeriğini araştırmak amaçlanmıştır. Çalışmada, bilgisayarda muhasebe uygulaması ve muhasebe bilgi 
sistemleri için ders taslağı için dört boyuta (önkoşul, durum, ders açıklaması ve konu kapsamı) göre içerik analizi yapılmıştır. Bilgisayarlarda ve muhasebe bilgi sistemlerinin incelendiği çalışmada lisans düzeyindeki 21 muhasebe müfredatı analiz edilmiştir. Yapılan çalışma sonucunda, lisans öğrencilerinin aldıkları eğitimlerinde e-muhasebe eğitimine çok az önem verildiği tespit edilmiştir. Bu nedenle çalışma sonucunda, muhasebe müfredatlarının güncellenmesi ve muhasebe meslek kuruluşları ile üniversiteler arasında bağlantı kurularak eğitim verilmesi gerektiği önerilmiştir.

Gönen ve Solak (2017), tarafından yapılan araştırmada, e-dönüşümü sürecine ilişkin muhasebe meslek mensuplarının, iş yükü, hizmet maliyeti vb. konulara bakış açılarını tespit etmek amaçlanmıştır. Bu amaç doğrultusunda İzmir'de faaliyet gösteren ve e-dönüşüm uygulamalarını aktif olarak kullanmakta olan muhasebe meslek mensuplarına anket uygulanmış ve anket sonucunda elde edilen bulgular analiz edilmiştir. Araştırma sonucunda e-dönüşüm süreci ve uygulamalarının muhasebe meslek mensupları için ek maliyetler doğurduğu, mükellefin bu ek maliyetleri ödemekten kaçındıkları ve muhasebe meslek mensuplarının yetersiz eğitim, sistemsel hatalar vb. nedenler sonucu bu süreçte en az bir kez hata yaptıkları tespit edilmiştir.

Garip ve Karasioğlu (2019), tarafindan gerçekleştirilen araştırma, e-uygulamaları yoğun olarak kullanan muhasebe meslek mensuplarının alanlarında yaşanan e-dönüşüm sürecinde karşılaşmış oldukları sorunların tespit edilmesi ve bu sorunlara çözüm önerileri sunulması amacıyla gerçekleştirilmiştir. Araştırmanın amac1 doğrultusunda Karaman Serbest Muhasebeci Mali Müşavirler Odasına kayıtlı olan 138 meslek mensubu ile anket çalışması yapılmıştır. Verilerin toplanmasının ardından yapılan analizler sonucunda, meslek mensuplarının e-dönüşüm süreci ile ilgili en büyük sorunun kalifiye eleman eksikliği olduğunu düşündükleri tespit edilmiştir.

Ghaffar vd. (2019), Malezya denizcilik endüstrisinde faaliyet gösteren KOBİ'ler için e-muhasebenin benimsenmesinde önem arz eden faktörleri belirlemek amacıyla yaptığı çalışmada; 103 KOBİ yöneticisi ile yüz yüze görüşme yoluyla 7'li likert ölçeğinde geliştirilen anketi uygulamıştır. Elde edilen verileri değerlendirmek amacıyla SPSS paket programını kullanmışlar ve regresyon analizinde e-muhasebe ile teknolojik, çevresel, örgütsel ve karar verici şeklinde dört bağımsız değişken arasındaki ilişkiyi ortaya koymaya çalışmıştır. Gerçekleştirilen regresyon analizi sonucunda en önemli bağımsız değişken olarak örgütsel değişken tespit edilirken, genel olarak kullanılan bağımsız değişkenlerin e-muhasebenin benimsenmesinde önemli rol oynadığı belirlenmiştir.

Kulak (2019), Malatya ilinde yer alan muhasebe meslek mensuplarının e-muhasebe hakkındaki görüşlerini araştırmak amacıyla yaptığı çalışmada, literatürden yararlanılarak geliştirilen ve 2 bölüm 29 sorudan oluşan anket formunu yüz yüze görüşme yöntemi ile muhasebe meslek mensuplarına uygulamıştır. 104 muhasebe meslek mensubuna anket uygulanmıştır. Yapılan çalışma sonucunda, muhasebe meslek mensupları ile edönüşüm arasında pozitif yönlü ve anlamlı ilişki bulmuşlardır.

Öztürk ve Çarıkçı (2019), tarafından yapılan çalışmada, gelecekte muhasebe mesleğini icra edecek birer aday olan öğrencilere verilen eğitimin elektronik muhasebe (e-muhasebe) açısından yeterliliğinin tespit edilmesi ve e-muhasebenin geleceğinin araştırılması amaçlanmıştır. Farklı üniversitelerde (Akdeniz Üniversitesi, Pamukkale Üniversitesi, Mehmet Akif Ersoy Üniversitesi, Süleyman Demirel Üniversitesi, Isparta Uygulamalı Bilimler Üniversitesi) ve meslek liselerinde eğitim alan lise, ön lisans, lisans ve lisansüstü seviyesindeki 1.133 öğrenci ile anket çalışması yapmışlardır. Anketler yardımıyla toplanan veriler SPSS ve AMOS paket programları ile analiz edilmiştir. Analizler sonucunda e-muhasebe ile ilgili eğitim, e-muhasebeye hazırlık ve gelecek algısı şeklinde üç boyutlu bir bakış açısı ortaya çıkarılmıştır. Öğrencilerin muhasebede yaşanan e-dönüşüm süreci ile ilgili olarak daha fazla bilgilendirilmesi ve yönlendirilmesinin öğrencilerin emuhasebe konusundaki geleceklerini olumlu etkileyeceğini belirtmişlerdir.

Çıtak ve Baskan (2020), tarafından yapılan çalışmada, Kırıkkale Serbest Muhasebeci Mali Müşavirler Odasına kayıtlı 51 muhasebe meslek mensubuna anket uygulanmıştır. Araştırmada muhasebe meslek mensuplarının muhasebede elektronik gelişmelerin muhasebe meslek etiği üzerindeki etkileri ile ilgili görüşlerinin tespit edilmesi amaçlanmıştır. Gerçekleştirilen anket uygulaması sonucunda, e-dönüşüm uygulamalarının meslek etiği davranışını etkilediği, mesleki özeni desteklediği, çalışanların altyapı eksikliğinin muhasebe meslek etik davranışını etkilediği, çalışanlara e-dönüşümle ilgili eğitim verilmemesinin muhasebe meslek etiği anlayışını etkilediği tespit edilmiştir. Muhasebe meslek mensuplarının demografik özelliklere göre e-dönüşümün melek etiğine etkisi arasında herhangi bir farklılık tespit edilememişsir.

\section{ARAŞTIRMA YÖNTEMI VE ELDE EDÍLEN BULGULAR}

$\mathrm{Bu}$ bölümde araştırmanın amacı ve hipotezleri, evreni, örneklemi, sınırlılıkları, yöntemi, kullanılan teknikler ve bulgular açıklanacaktır.

Selçuk Üniversitesi Sosyal Bilimler Meslek Yüksekokulu Dergisi, Yıl: 2020 Cilt: 23 Sayı:2 


\subsection{Araştırmanın Amacı ve Hipotezleri}

E-dönüşüm süreci ile hayatımızın her alanında yer bulan e-uygulamaların kullanıcılarından biri olan muhasebe meslek mensuplarının görüşlerinin alınarak değerlendirilmesi önem arz etmektedir. Bu doğrultuda çalışmanın amacı; muhasebe meslek mensuplarının e-dönüşüm sürecine ilişkin görüş ve beklentileri tespit edebilmek ve araştırma sonucu ortaya çıkan sorunlar için çözüm önerileri sunabilmektir.

Araştırmanın hipotezleri ise aşağıdaki şekilde belirlenmiştir.

$\mathrm{H}_{1}$ : Muhasebe meslek mensuplarının demografik özelliklerine göre e-dönüşüm uygulamaları hakkındaki görüşleri farklılaşmaktadır.

$\mathrm{H}_{2}$ : Muhasebe meslek mensuplarının bilgi düzeylerine göre e-dönüşüm uygulamaları hakkındaki görüşleri farklılaşmaktadır.

$\mathrm{H}_{3}$ : Muhasebe meslek mensuplarının müşteri işletmeleri dijital muhasebe süreçleri ile ilgili değerlendirmelerine göre e-dönüşüm uygulamaları hakkındaki görüşleri farklılaşmaktadır.

$\mathrm{H}_{4}$ : Muhasebe meslek mensuplarının kamu kurum ve kuruluşlarını dijital muhasebe süreçleri ile ilgili değerlendirmelerine göre e-dönüşüm uygulamaları hakkındaki görüşleri farklılaşmaktadır.

$\mathrm{H}_{5}$ : Muhasebe meslek mensuplarının mesleki kuruluşlara ilişkin (TURMOB) dijital muhasebe süreçleri ile ilgili değerlendirmelerine göre e-dönüşüm uygulamaları hakkındaki görüşleri farklılaşmaktadır.

\subsection{Araştırmanın Evreni}

Çalışmada ana kütleyi Hatay ilinde faaliyet gösteren ve bağımsız çalışan Serbest Muhasebeci ve Mali Müşavirler (SMMM) oluşturmaktadır. Hatay Serbest Muhasebeci ve Mali Müşavirler odasına kayıtlı toplam 722 SMMM olup, 438'i merkez ilçe olan Antakya' da faaliyet göstermektedir (HSMMMO, 2020). Çalışmanın evrenini merkez ilçe Antakya'da faaliyet gösteren 438 SMMM oluşturmaktadır.

\subsection{Araştırmanın Örneklemi}

Sosyal bilimler alanında yapılan araştırmalarında en çok kullanılan örneklem büyüklüğü hesaplanma formülü Cochran tarafından geliştirilen hesaplama tekniğidir. Nicel değişkenler içeren bir araştırma için bu tekniğe ait örneklem hesaplama formülü ve formülde yer alan terimlerin anlamlarını ifade eden açıklamalar aşağıdaki gibidir (Gürbüz ve Şahin, 2018: 128).

$$
\begin{aligned}
n & =\frac{n_{0}}{1+\frac{n_{0}}{N}} \\
n_{0} & =\frac{t^{2} x s^{2}}{d^{2}}
\end{aligned}
$$

N: evren büyüklüğ̈̈, n: örneklem büyüklüğü

$\mathrm{t}$ : güven düzeyine karşıllı gelen tablo

$\mathrm{z}$ değeri $(0.05$ için $1.96,0.01$ için 2.58 ve 0.001 için 3.28$)$

$\mathrm{s}$ : evren için tahmin edilen standart sapma

d: kabul edilebilir sapma tolerans1

Formülden yararlanılarak evren büyüklüğünü oluşturan 438 adet SMMM'nin, $t$ istenilen anlamlılık düzeyi $\% 5$ (z değeri 1,96$)$ ve d kabul edilebilir $( \pm 5)$ sapma toleransı ile asgari örneklem büyüklügü 205 olarak bulunmuştur.

$$
\begin{aligned}
n_{0}= & \frac{1,96^{2} x 0,5^{2}}{0,05^{2}}=384,16 \\
& n=\frac{384,16}{1+384,16 / 438}=204,69
\end{aligned}
$$

438 muhasebe meslek mensubundan 208 tanesi anket uygulamasına katılmayı kabul etmiş ve anket uygulaması yapılmıştır. Böylece asgari örneklem büyüklüğü sağlanarak gerekli veriler elde edilmiştir.

\subsection{Araştırmanın Sınırılııkları}

Çalışmada Hatay SMMMO'ya kayıtlı muhasebe meslek mensuplarının tümüne ulaşılmamıştır ve bu nedenle çalışma sadece Merkez ilçeler olan Antakya'da faaliyetlerine devam eden muhasebe meslek mensupları ile sınırlandırılmıştır. Bu durum genellenebilirlik düzeyini düşürmektedir.

\subsection{Metodoloji}

Çalışmada veri toplama yöntemi olarak anket yöntemi seçilmiştir. Anket verileri yüz yüze görüşme tekniği ile elde edilmiştir. Anket toplama sürecine 20.07.2020 tarihinde başlanmış ve 28.08.2020 tarihinde tamamlanmıştır. 
Çalışmada Durmuş (2018) tarafından geliştirilen ve Malatya ilinde faaliyet gösteren muhasebe meslek mensupları üzerine uygulanan anket formu kullanılmıştır. Anket, iki bölümden oluşmaktadır. Birinci bölümde muhasebe meslek mensuplarının demografik özelliklerini ve çalışma koşullarını araştırmak amacıyla kapalı uçlu sorulara yer verilmiştir. İkinci bölümde "muhasebe meslek mensuplarının bilgi düzeyleri ve görüşleri" (20 tane ifade), "müşteri işletmelerin dijital muhasebe süreçlerinde değerlendirilmeleri" (6 tane ifade), "kamu kurum ve kuruluşlarının dijital muhasebe süreçlerinde değerlendirilmeleri" (13 tane ifade) ve "mesleki kuruluşlara ilişsin değerlendirmeler (TURMOB)" (8 tane ifade) olacak şekilde toplam 47 ifadeye yer verilmiştir. Bu bölüme ait sorularda "Beşli Likert Tipi" (5: Kesinlikle Katılıyorum, 4: Katılıyorum, 3: Ne Katılıyorum Ne Katılmıyorum, 2: Katılmıyorum, 1: Kesinlikle Katılmıyorum) ölçek kullanılmıştır. Anket verilerinin analizi için SPSS 22 (Statistical Package for the Social Scienes / Sosyal Bilimler İçin İstatistik Programı) istatistik programı kullanılmıştır ve ölçek güvenilirliği SPSS Cronbach's Alpha $(\alpha)$ değerine göre belirlenmiştir.

Cronbach Alfa Katsayısı, $0.00 \leq \alpha \leq 0.40$ aralığında ise ölçeğin güvenilir olmadığını, $0.40 \leq \alpha \leq 0.60$ aralığında ise ölçeğin güvenilirliği düşük, $0.60 \leq \alpha \leq 0.80$ aralığında ise ölçek oldukça güvenilir ve $0.80 \leq \alpha \leq$ 1.00 aralığında ise ölçek yüksek derecede güvenilirdir (Kalayc1, 2010: 405). 47 adet ifade içeren veri toplama aracının güvenilirlik katsayısı testi sonucunda Cronbach's Alpha değeri 0,806 olarak hesaplanmış olup hesaplanan bu değer araştırmanın güvenilirliğinin yüksek olduğunu göstermektedir.

\subsection{Verilerin Analizi}

Muhasebe meslek mensuplarını e - dönüşümün hakkındaki görüşlerini belirlemek üzere uygulanan anketlerden elde edilen verilerin analizi aşağıdaki gibidir.

Tablo 1: Araştırmaya Katılan Muhasebe Meslek Mensuplarına Ait Demografik Bilgiler

\begin{tabular}{|c|c|c|c|c|}
\hline \multicolumn{2}{|c|}{ Demografik Bilgiler } & \multirow{2}{*}{\begin{tabular}{|c} 
Frekans \\
145 \\
63
\end{tabular}} & \multirow{2}{*}{$\begin{array}{c}\text { Oran }(\%) \\
69,7 \\
30,3\end{array}$} & \multirow{2}{*}{$\begin{array}{c}\begin{array}{c}\text { Kümülatif } \\
\text { Oran (\%) }\end{array} \\
69,7 \\
100,0\end{array}$} \\
\hline Cinsiyet & $\begin{array}{l}\text { Erkek } \\
\text { Kadın } \\
\end{array}$ & & & \\
\hline Yaş & \begin{tabular}{|l|}
$25-30$ yaş aras1 \\
$31-40$ yaş aras1 \\
$41-50$ yaş aras1 \\
$51-60$ yaş aras1 \\
61 yaş ve üzeri \\
\end{tabular} & $\begin{array}{l}30 \\
70 \\
74 \\
21 \\
13 \\
\end{array}$ & $\begin{array}{c}14,4 \\
33,7 \\
35,6 \\
10,1 \\
6,3 \\
\end{array}$ & $\begin{array}{c}14,4 \\
48,1 \\
83,7 \\
93,8 \\
100,0 \\
\end{array}$ \\
\hline Eğitim Durumu & \begin{tabular}{|l} 
Önlisans \\
Lisans \\
Yüksek Lisans
\end{tabular} & $\begin{array}{c}15 \\
175 \\
18\end{array}$ & $\begin{array}{c}7,2 \\
84,1 \\
8,7\end{array}$ & $\begin{array}{c}7,2 \\
91,3 \\
100,0\end{array}$ \\
\hline Mesleki Deneyim Süresi & $\begin{array}{l}1-5 \text { yıl aras1 } \\
6-10 \text { y1l aras1 } \\
11-15 \text { yıl aras1 } \\
16-20 \text { y1l aras1 } \\
21-25 \text { yıl aras1 } \\
26 \text { y1l ve üzeri }\end{array}$ & $\begin{array}{l}32 \\
58 \\
72 \\
22 \\
10 \\
14\end{array}$ & $\begin{array}{c}15,4 \\
27,9 \\
34,6 \\
10,6 \\
4,8 \\
6,7\end{array}$ & $\begin{array}{c}15,4 \\
43,3 \\
77,9 \\
88,5 \\
93,3 \\
100,0\end{array}$ \\
\hline Hizmet Verdiği Müşteri Sayısı & \begin{tabular}{|l|}
$1-25$ aras1 \\
$26-50$ aras1 \\
$51-75$ aras1 \\
$76-100$ aras1 \\
101 ve üzeri \\
\end{tabular} & $\begin{array}{l}11 \\
27 \\
71 \\
75 \\
24 \\
\end{array}$ & $\begin{array}{c}5,3 \\
13,0 \\
34,1 \\
36,1 \\
11,5 \\
\end{array}$ & $\begin{array}{c}5,3 \\
18,3 \\
52,4 \\
88,5 \\
100,0 \\
\end{array}$ \\
\hline Aylık Gelir Düzeyi & $\begin{array}{l}3000 \text { TL den az } \\
3001-5000 \mathrm{TL} \text { aras1 } \\
5001-7500 \mathrm{TL} \text { aras1 } \\
7501-10000 \mathrm{TL} \text { aras } \\
10001 \mathrm{TL} \text { ve üzeri }\end{array}$ & $\begin{array}{c}14 \\
32 \\
102 \\
36 \\
24\end{array}$ & $\begin{array}{c}6,7 \\
15,4 \\
49,0 \\
17,3 \\
11,5\end{array}$ & $\begin{array}{c}6,7 \\
22,1 \\
71,2 \\
88,5 \\
100,0\end{array}$ \\
\hline Bürosunda Çalıştırdığı Personel Sayıs1 & $\begin{array}{l}0-3 \text { kişi aras1 } \\
\text { 4-6 kişi aras1 } \\
7-9 \text { kişi arası } \\
10-12 \text { kişi aras1 } \\
13 \text { kişi ve üzeri }\end{array}$ & $\begin{array}{c}32 \\
83 \\
71 \\
16 \\
6\end{array}$ & $\begin{array}{c}15,4 \\
39,9 \\
34,1 \\
7,7 \\
2,9\end{array}$ & $\begin{array}{c}15,4 \\
55,3 \\
89,4 \\
97,1 \\
100,0\end{array}$ \\
\hline
\end{tabular}




\begin{tabular}{|l|l|c|c|c|}
\hline & 1 saatten az & 2 & 1,0 & 1,0 \\
İnternet Vergi Dairesi Günlük & 1-2 saat arası & 18 & 8,7 & 9,6 \\
Kullanım Süresi & 3-4 saat arası & 111 & 53,4 & 63,0 \\
& 5-6 saat aras1 & 66 & 31,7 & 94,7 \\
\hline
\end{tabular}

Anketin ilk bölümü muhasebe meslek mensuplarının demografik özelliklerini belirlemeyi amaçlayan kapalı uçlu 7 sorudan oluşmaktadır.

Tablo 1'e göre araştırmaya katılan muhasebe meslek mensuplarının yüzde 69,7'sinin erkek, yüzde 30,3'ünün ise kadın olduğu görülmektedir. Meslek mensupları arasında 41 yaş ve altında olanların oranı yüzde 48,1 iken 41 yaş ve üzeri olanların oranı yüzde 51,9'dur. Katılımcıların ağırlıklı olarak lisans mezunu olduğu ve doktora mezunu meslek mensubu bulunmadığı görülmektedir. Burada meslek mensuplarının lisansüstü eğitime yönelmeleri, muhasebe alanındaki güncel gelişmeleri takip edebilmeleri açısından önem arz etmektedir. Katılımcıların yüzde 77,9'unun 16 yıldan daha az mesleki tecrübeye sahip olduğu görülmektedir. Araştırmaya katılan meslek mensuplarının hizmet verdiği müşteri sayısına göre dağılımı incelendiğinde ağırlıklı olarak yüzde 34,1'inin 51-75 aras1 müşterisi, yüzde 36,1'inin 76-100 aras1 müşterisi olduğu görülmektedir. Müşteri sayısının artması ile birlikte baskılama, yazdırma, postalama, elde edilen verilerin saklanması gibi maliyetler de arttırmaktadır. Çevre dostu olarak da ifade edilebilecek muhasebede yaşanan edönüşüm süreçlerinin tamamlanması ile birlikte bu sorunlar ortadan kalkacaktır. Aylık gelir düzeyi yüzde 49 ile 5001-7500 TL arasında yoğunlaşmış olup, katılımcıların 71,2'sinin aylık geliri 7501 TL'den daha düşüktür. Muhasebe meslek mensuplarının aylık gelirlerinin yüksek olması e-dönüşüm sürecinde gerekli olan teknolojik altyapıya ulaşmalarını kolaylaştıracak önemli bir etkendir. Araştırmaya katılan meslek mensuplarının bürolarında çalıştırdığı personel sayılarına göre dağılımı incelendiğinde yüzde 39,9'unun 4-6 arasında, yüzde 34,1'inin 7-9 arasında personeli olduğu görülmektedir. Personellerin etkisini ve sayısını azaltmaya neden olan dijital dönüşümlerin varlığı, personelleri mesleki bilgilerinin yanı sıra bilgi teknolojileri ile ilgili gelişmeleri yakından takip ediyor ve alanları ile ilgili yazılımlan kullanabiliyor olmaya itmektedir. İnternet Vergi Dairesi'ni bir günde kullanma sıklığı incelendiğinde meslek mensuplarının yüzde 63'ünün 5 saatten daha az kullandıkları görülmektedir.

Anketin ikinci bölümü Beşli Likert Tipi ölçek şeklindedir ve 4 kısımdan oluşmaktadır. İlk kısımda muhasebe meslek mensuplarının bilgi düzeyleri ve görüşleri, ikinci kısımda müşteri işletmeleri dijital muhasebe süreçleri ile ilgili değerlendirmeleri, üçüncü kısımda kamu kurum ve kuruluşlarını dijital muhasebe süreçleri ile ilgili değerlendirmeleri ve son kısımda ise mesleki kuruluşlara ilişkin (TURMOB) dijital muhasebe süreçleri ile ilgili değerlendirmeleri yer almaktadır.

Tablo 2: Muhasebe Meslek Mensuplarının Bilgi Düzeyleri ve Görüşleri

\begin{tabular}{|c|c|c|c|c|c|c|}
\hline İfadeler & 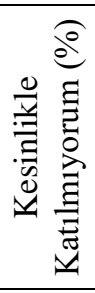 & 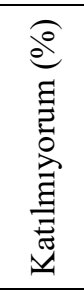 & 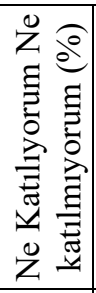 & 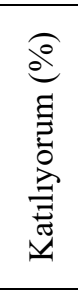 & 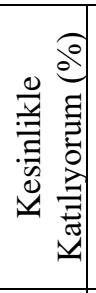 & 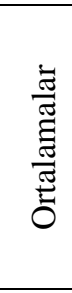 \\
\hline 1.Dijital muhasebede kendinizi yeterli görüyor musunuz? & 18,3 & 7,7 & 13,9 & 18,3 & 41,8 & 3,58 \\
\hline 2.Dijital muhasebe ile ilgili eğitim aldınız mı? & 15,9 & 19,2 & 17,8 & 14,9 & 32,2 & 3,28 \\
\hline 3.Dijital muhasebe eğitimine ihtiyaç duyuyor musunuz? & 12,0 & 8,7 & 28,4 & 13,0 & 38,0 & 3,56 \\
\hline $\begin{array}{l}\text { 4.Dijital muhasebe ile ilgili sürekli eğitimlerin olması gerektiğini } \\
\text { düşünüyor musunuz? }\end{array}$ & 6,3 & 11,1 & 22,1 & 15,9 & 44,7 & 3,82 \\
\hline 5.Ofisinizin teknolojik değişime uyumunu gerçekleştirdiniz mi? & 11,5 & 15,4 & 31,7 & 20,2 & 21,2 & 3,24 \\
\hline $\begin{array}{l}\text { 6.Ofis personeliniz için işyerinizde sürekli teknolojik değişim ve } \\
\text { mevzuat değişimi uyum eğitimi yapıyor musunuz? }\end{array}$ & 12,0 & 20,7 & 31,3 & 19,7 & 16,3 & 3,08 \\
\hline $\begin{array}{l}\text { 7.Ofisinizdeki Teknolojik alt yapı iyileştirmelerinin önemli ekonomik } \\
\text { maliyetleri olduğunu düşünüyor musunuz? }\end{array}$ & 2,9 & 15,4 & 23,1 & 21,6 & 37,0 & 3,75 \\
\hline $\begin{array}{l}\text { 8.Dijital muhasebe uygulamalarını gerçekleştirebilecek ek personel } \\
\text { istihdamınız oldu mu? }\end{array}$ & 31,3 & 22,1 & 21,6 & 12,5 & 12,5 & 2,53 \\
\hline
\end{tabular}




\begin{tabular}{|c|c|c|c|c|c|c|}
\hline 9. Dijital muhasebeye geçişten dolayı personel azaltımı yaptınız mı? & 34,6 & 22,1 & 25,0 & 11,5 & 6,7 & 2,34 \\
\hline 10. E-defter müşterilerinizin ücretlendirme sisteminde artışlar oldu mu? & 7,2 & 21,2 & 24,0 & 22,6 & 25,0 & 3,37 \\
\hline $\begin{array}{l}\text { sleğindeki dijital dönüşümün mesleğe katkısı olduğunu } \\
\text { nuz? }\end{array}$ & 13,5 & 18,3 & 31,7 & 16,3 & 20,2 & 3,12 \\
\hline $\begin{array}{l}\text { 12.Muhasebe mesleğindeki dijital dönüşümün ekonomiye katkıs1 } \\
\text { olduğunu düşünüyor musunuz? }\end{array}$ & 9,6 & 22,6 & 26,0 & 23,1 & 18,8 & 3,19 \\
\hline $\begin{array}{l}\text { tal dönüşümün kayıt dışıllı̆ } 1 \\
\text { sunuz? }\end{array}$ & 14,4 & 20,2 & 26,0 & 20,7 & 18,8 & 3,09 \\
\hline $\begin{array}{l}\text { 14.Muhasebe mesleğind } \\
\text { önlemeye katk1 sağlayac }\end{array}$ & 13,5 & 20,7 & 26,0 & 20,7 & 19,2 & 3,12 \\
\hline $\begin{array}{l}\text { 15.Muhasebe mesleğindeki e-dönüşümün yolsuzluk ve suiistimalleri } \\
\text { önleyeceğini düşünüyor musunuz? }\end{array}$ & 14,9 & 23,6 & 29,8 & 16,3 & 15,4 & 2,94 \\
\hline $\begin{array}{l}\text { 16.Muhasebe mesleğindeki e-dönüşümün meslekte kurumsallaşmaya } \\
\text { yardımcı olacağını düşünüyor musunuz? }\end{array}$ & 8, & 23,1 & 28,8 & 22,1 & 17,8 & 3,18 \\
\hline $\begin{array}{l}\text { 17.Muhasebe mesleğindeki e-dönüşümün tahsilat sorununuzun } \\
\text { çözümüne katk1 sağlayacağını düşünüyor musunuz? }\end{array}$ & 19,2 & 20,2 & 27,4 & 17,8 & 15,4 & 2,90 \\
\hline $\begin{array}{l}\text { 18.Bir uygulayıcı olarak gelecekte değişen muhasebe mesleğinin } \\
\text { öneminin artacağını düşünüyor musunuz? }\end{array}$ & 8, & 15,9 & 25,0 & 25,0 & 25,5 & 3,43 \\
\hline $\begin{array}{l}\text { 19.Dijital muhasebe ile işlemlerin hızlanmasının kendinize ve ailenize } \\
\text { daha fazla zaman ayırmaya yardımcı olacağını düşünüyor musunuz? }\end{array}$ & 15,9 & 17,8 & 25,0 & 16,3 & 25,0 & 3,17 \\
\hline $\begin{array}{l}\text { 20.E-Dönüşüm ve dijital muhasebenin uygulamasiyla birlikte meslek } \\
\text { mensubunun müteselsil ve müsstereken sorumluluğunu yeniden } \\
\text { düzenlenmesi gerekiyor mu? }\end{array}$ & 6,3 & 11,1 & 32,2 & 16,3 & 34,1 & 3,61 \\
\hline
\end{tabular}

Tablo 2'de yer alan muhasebe meslek mensuplarının e-dönüşüm uygulamaları ile ilgili bilgi düzeyleri ve görüşlerinin ortalaması 3,21'dir. Bu kısımda yer alan ifadelerden "4.Dijital muhasebe ile ilgili sürekli eğitimlerin olması gerektiğini düşünüyor musunuz?" ifadesi 3,82 (4 Katılıyorum'a daha yakın) seviyesi ile en yüksek ortalamaya sahiptir. "9. Dijital muhasebeye geçişten dolayı personel azaltımı yaptınız mı?" ifadesi ise 2,34 (2 Katılmıyorum'a daha yakın) seviyesi ile en düşük ortalamaya sahiptir.

Katılımciların yüzde 60,1'i dijital muhasebede kendilerini yeterli görmektedir. Dijital muhasebe ile ilgili eğitim aldıklarını ifade eden katılımcıların oranı yüzde 47,1 iken yüzde 51,0'i dijital muhasebe eğitimine ihtiyaç duyduğunu ifade etmektedir. Yüzde 60,6 's1 ise sürekli eğitimlerin olmas1 gerektiğini düşünüyor. Katılımcıların sadece yüzde 41,4'ü ofislerinde teknolojik altyapı kurulumunu tamamlamış ve yüzde 36'sı ofis personeline yardımcı olmak için teknolojik değişim ve mevzuat değişimi uyum eğitimi vermiştir. Katılımcıların ofisindeki yüzde 58,6's1 teknolojik alt yap1 iyileştirmelerinin önemli ekonomik maliyetleri olduğunu düşünmektedir. Katılımcıların yüzde 53,4'ü dijital muhasebe uygulamalarını gerçekleştirebilecek ek personel istihdamı yapmadıklarını belirtirken yüzde 56,7'si dijital muhasebeye geçişten dolayı personellerini işten çıkarmadıklarını belirtmişlerdir. Buradan hareketle araştırmaya katılan muhasebe meslek mensuplarının yarısından fazlası dijital muhasebeye geçiş süreci nedeniyle ek personel alımı yapmadıkları gibi işten çıkarma da yapmamışlardır. E-defter müşterilerinizin ücretlendirme sisteminde artışlar yaşandığını ifade eden katılımcıların oranı yüzde 47,6'dır. Katılımcıların yüzde 36,5'i dijital muhasebenin muhasebe mesleğine olumlu katkı sağlayacağına inanıyor. Aynı zamanda katılımcıların 41,9'u dijital muhasebenin ülke ekonomisine pozitif anlamda etkileyeceğine inanmaktadır. 39,5'i ekonomide kayıt dış1lığı, yüzde 39,9'u dijital muhasebenin meslekteki haksız rekabeti önleyebileceğine inanıyor.

Muhasebe mesleğindeki e-dönüşümün meslekte kurumsallaşmayı olumlu yönde etkileyeceğine inananların oranı yüzde 39,9 ve muhasebe mesleğinin öneminin artacağını düşünenlerin oranı yüzde 50,5'tir. Buradan hareketle muhasebede yaşanan dijital dönüşüm ile birlikte muhasebe mesleğinin öneminin artacağ1; meslek mensuplarının kayıt tutma iş yükünü bilgi teknolojileri ile gelen yazılımlara devrederek, ardından gelen süreçte daha çok raporlama, denetim ve danışmanlık alanlarına yoğunlaşıp hizmet verecekleri ifade edilebilir. Muhasebe meslek mensuplarının dijital muhasebe ile işlemlerin hızlanmasının kendisine ve ailesine daha fazla zaman ayırmaya yardımcı olduğunu ifade etmekteler.

Ancak katılımcılar yolsuzluk ve suiistimalleri önlenmede bir etkisinin olmayacağını, tahsilat sorununuzun çözümüne katkı sağlamayacağını düşünmektedirler. Ayrıca katılımcıların yüzde 50,4'ü e-dönüşüm ve dijital muhasebenin uygulamasıyla birlikte meslek mensubunun müteselsil ve müştereken sorumluluğunu yeniden düzenlenmesi gerekliliğine dikkat çekmişlerdir. 
Tablo 3: Muhasebe Meslek Mensuplarının Müşteri İşletmeleri Dijital Muhasebe Süreçleri İle İlgili Değerlendirmeleri

\begin{tabular}{|c|c|c|c|c|c|c|}
\hline İfadeler & 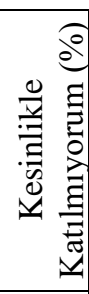 & 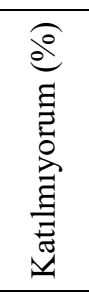 & 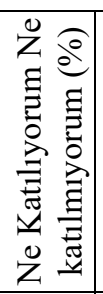 & 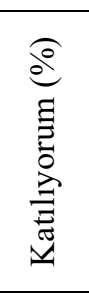 & 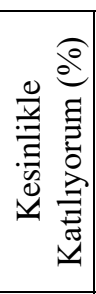 & 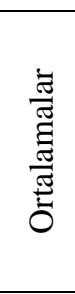 \\
\hline $\begin{array}{l}\text { 1.Müşterilerinizin E-dönüşüm (e-defter,e-belge,e-beyan vb.) ile ilgili } \\
\text { yeterli bilgiye sahip olduklarını düşünüyor musunuz? }\end{array}$ & 35,1 & 34,6 & 19,2 & 6,7 & 4,3 & 2,11 \\
\hline $\begin{array}{l}\text { 2.Müşterilerinizin e-dönüşüm sürecine yaklaşımlarının olumlu olduğunu } \\
\text { düşünüyor musunuz? }\end{array}$ & 28,4 & 32,7 & 27,4 & 9,6 & 1,9 & 2,24 \\
\hline $\begin{array}{l}\text { 3.Müşterilerinizin teknik alt yapılarının e-dönüşüm süreci için yeterli } \\
\text { olduğunu düşünüyor musunuz? }\end{array}$ & 28,4 & 28,8 & 25,5 & 9,6 & 7,7 & 2,39 \\
\hline $\begin{array}{l}\text { 4.Müşterilerinizin yüksek maliyetler nedeniyle e-dönüşüm sürecine uyum } \\
\text { için teknik alt yapılarını iyileştirme niyetlerinin olduğunu düşünüyor } \\
\text { musunuz? }\end{array}$ & 42,3 & 28,8 & 21,6 & 2,9 & 4,3 & 1,98 \\
\hline $\begin{array}{l}\text { 5.E-defter uygulamalarından dolayı yapılan ücret artışlarına } \\
\text { müşterilerinizin olumlu yaklaştıklarını düşünüyor musunuz? }\end{array}$ & 30,3 & 33,2 & 27,9 & 5,3 & 3,4 & 2,18 \\
\hline $\begin{array}{l}\text { 6. Dijital muhasebenin piyasa ve şirketlerin şeffaflığının ve hesap } \\
\text { verilebilirliğini artıracağını düşünüyor musunuz? }\end{array}$ & 10,6 & 17,3 & 24 & 13,5 & 34,6 & 3,44 \\
\hline
\end{tabular}

Tablo 3'te yer alan muhasebe meslek mensuplarının müşteri işletmeleri dijital muhasebe süreçleri ile ilgili değerlendirmeleri içeren ifadelere verilen cevapların ortalaması 2,39'dur. Tablodan anlaşılacağı üzere katılımcıların genellikle müşteri işletmesinin dijital muhasebeye ilişkin bilgi düzeyinin ve teknolojik altyapısının yeterli olmadığını düşündükleri ifade edilebilir. Bu kısımda yer alan ifadelerden " 6 . Dijital muhasebenin piyasa ve şirketlerin şeffaflığının ve hesap verilebilirliğini artıracağını düşünüyor musunuz?" ifadesi 3,44 (4 Katılıyorum'a daha yakın) seviyesi ile en yüksek ortalamaya sahiptir. "4.Müşterilerinizin yüksek maliyetler nedeniyle e-dönüşüm sürecine uyum için teknik alt yapılarını iyileştirme niyetlerinin olduğunu düşünüyor musunuz?” ifadesi ise 1,98 (2 Katılmıyorum'a daha yakın) seviyesi ile en düşük ortalamaya sahiptir.

Araştırmaya katılan muhasebe meslek mensuplarının yüzde 69,7'si müşterilerinin muhasebede e-dönüşüm ile ilgili yeterli bilgiye sahip olmadıklarını ve yüzde 61,1'i e-dönüşüm sürecine yaklaşımlarının olumlu olmadığını düşünüyor. Ayrıca katılımcılar, müşteri işletmelerinin teknik altyapısının e-dönüşüm süreci için yeterli olmadığını buna ek olarak müşteri işletmelerinin yüksek maliyetler nedeniyle e-dönüşüm sürecine uyum için teknik alt yapılarını iyileştirme niyetlerinin olmadığını düşünmektedir.

Son olarak katılımcıların yüzde 48,1'i dijital muhasebenin piyasa ve şirketlerin şeffaflığın ve hesap verilebilirliğinin artmasına katkı sağladığına inanmaktadır.

Tablo 4: Muhasebe Meslek Mensuplarının Kamu Kurum ve Kuruluşlarını Dijital Muhasebe Süreçleri İle İlgili Değerlendirmeleri

\begin{tabular}{|c|c|c|c|c|c|c|}
\hline İfadeler & 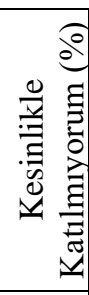 & 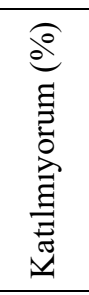 & 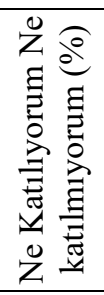 & 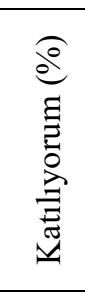 & 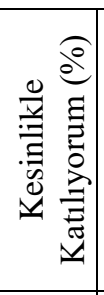 & 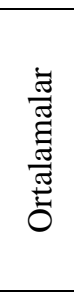 \\
\hline $\begin{array}{l}\text { 1-Kamu kurum ve kuruluşlarının mesleğe bakış açılarının olumlu } \\
\text { olduğunu düşünüyor musunuz? }\end{array}$ & 13,5 & 15,9 & 26,0 & 12,0 & 32,7 & 3,35 \\
\hline $\begin{array}{l}\text { 2. Farklı kamu kurumlarının farklı dijital alt yapılar kullanması dijital } \\
\text { muhasebe uygulamalarında sorun yaratmakta mıdır? }\end{array}$ & 19,2 & 31,3 & 32,7 & 9,6 & 7,2 & 2,54 \\
\hline
\end{tabular}




\begin{tabular}{|l|c|c|c|c|c|c|}
\hline $\begin{array}{l}\text { 3.E-Dönüşüm sürecinde yeterli pilot uygulamaların yapıldığını düşünüyor } \\
\text { musunuz? }\end{array}$ & 14,9 & 34,6 & 30,8 & 14,9 & 4,8 & 2,60 \\
\hline $\begin{array}{l}\text { 4.E-dönüşüm geçiş sürecinin yeterli uzunlukta olduğunu düşünüyor } \\
\text { musunuz? }\end{array}$ & 15,4 & 32,2 & 34,1 & 14,9 & 3,4 & 2,59 \\
\hline $\begin{array}{l}\text { 5.Kamu kurumlarının e-dönüşüm uygulama kararlılığının yeterli } \\
\text { olduğunu düşünüyor musunz? }\end{array}$ & 10,1 & 32,2 & 35,6 & 16,8 & 5,3 & 2,75 \\
\hline $\begin{array}{l}\text { 6.E-dönüşüm sürecine geçişte kamu kurumlarının işletmelerin ve } \\
\text { muhasebe meslek mensuplarının fiziki ve teknik bilgi yeterliliklerini } \\
\text { dikkate aldı̆ını düşünüyor musunuz? }\end{array}$ & 19,2 & 29,8 & 28,4 & 16,8 & 5,8 & 2,60 \\
\hline $\begin{array}{l}\text { 7.Kamu kurumları personellerinin e-dönüşüm için yeterli eğitime ve } \\
\text { bilgiye sahip olduğunu düşünüyor musunuz? }\end{array}$ & 14,9 & 33,2 & 32,2 & 12,5 & 7,2 & 2,64 \\
\hline $\begin{array}{l}\text { 8.Elektronik ortamda kamu kurumlarına (Gelir İdaresi Başkanlığı vb.) } \\
\text { erişimde sıkıntı yaşandığını düşünüyor musunuz? }\end{array}$ & 13 & 29,3 & 24,5 & 18,8 & 14,4 & 2,92 \\
\hline $\begin{array}{l}\text { 9.Erişim aksaklıklarından dolayı beyannamelerin zamanında } \\
\text { verilmemesine dair problemler yaşandığını düşünüyor musunuz? }\end{array}$ & 13,0 & 24,5 & 29,3 & 17,8 & 15,4 & 2,98 \\
\hline $\begin{array}{l}\text { 10.E-dönüşüm ile ilgili mevzuat değişikliklerinin bilişşm sistemine } \\
\text { zamanında entegre edilebildiğini düşünüyor musunuz? }\end{array}$ & 9,1 & 19,7 & 32,7 & 20,7 & 17,8 & 3,18 \\
\hline $\begin{array}{l}\text { 11.Dijital muhasebenin bilgi kullanıcıları arasında bilgi paylaşımı ve } \\
\text { kontrolde faydalı olacağını düşünüyor musunuz? }\end{array}$ & 10,1 & 23,6 & 26 & 22,6 & 17,8 & 3,14 \\
\hline $\begin{array}{l}\text { 12.E-Dönüsüm ve Dijital muhasebe sürecinde e-şifrelerin ve yetki } \\
\text { kullanımlarından doğabilecek sorunlardan güvenlik ve gizlilik açısından } \\
\text { endişe duyuyor musunuz? }\end{array}$ & 14,4 & 19,7 & 28,8 & 16,3 & 20,7 & 3,09 \\
\hline $\begin{array}{l}\text { 13.Bilgi teknolojileri kullanılarak üniversitelerde yeni bir muhasebe } \\
\text { eğitim modeli oluşturulmalı mıdır? }\end{array}$ & 9,1 & 18,3 & 22,1 & 15,4 & 35,1 & 3,49 \\
\hline
\end{tabular}

Tablo 4'te yer alan muhasebe meslek mensuplarının kamu kurum ve kuruluşlarını dijital muhasebe süreçleri ile ilgili değerlendirmeleri içeren ifadelere verilen cevapların ortalaması 2,91'dir. Bu ortalamadan hareketle katılımcıların kamu kurum ve kuruluşlarının dijital muhasebe konusundaki yaklaşımları konusunda memnun olmadıkları ifade edilebilir. Bu kısımda yer alan ifadelerden "13.Bilgi teknolojileri kullanılarak üniversitelerde yeni bir muhasebe eğitim modeli oluşturulmalı mıdır?" ifadesi 3,49 (4 Katılıyorum'a daha yakın) seviyesi ile en yüksek ortalamaya sahiptir. "2. Farklı kamu kurumlarının farklı dijital alt yapılar kullanması dijital muhasebe uygulamalarında sorun yaratmakta midır?” ifadesi ise 2,54 (3 Ne Katılıyorum Ne Katılmıorum'a daha yakın) seviyesi ile en düşük ortalamaya sahiptir.

Katılımcılar kamu kuruluşlarının birbirlerinden farklı dijital altyapıları kullanmasının dijital muhasebe uygulamalarında sorun yarattığını düşünüyor. Ayrıca katılımcılar e-dönüşüm geçiş sürecinde aksaklıkların yaşandığını belirten şu ifadelere katılım oranları sırasıyla; yüzde 49,5 ile yeterli pilot programların yapılmadığ1, yüzde 47,6 ile e-dönüşüm geçiş sürecinin yeterince uzun olmadığ kurumlarının e-dönüşüm uygulama kararlılığının yeterli olmadığı, yüzde 49 ile kamu kurumlarının işletmelerin ve muhasebe meslek mensuplarının fiziksel ve teknik yeterliliklerinin dikkate alınmadığı; yüzde 48,1 ile kamu kurumlarındaki personelin e-dönüşüm ile ilgili yeterli bilgiye sahip olmadığı şeklindedir. Tüm bu sorunlara ek olarak katılımcıların yüzde 42,3’ü kamu kurumlarına (Gelir İdaresi Başkanlığı vb.) elektronik ortamda erişimde sıkıntı yaşamakta ve bu erişim aksaklıkları neticesinde beyannamelerin teslim edilememesine dair problemler yaşamaktadır. Muhasebe meslek mensupları e-dönüşüm ve dijital muhasebe sürecinde e-şifrelerin ve yetki kullanımlarından doğabilecek sorunlardan güvenlik ve gizlilik açısından sorun yaratacağına dair endişeleri bulunmaktadır.

Muhasebe meslek mensuplarının kamu kurum ve kuruluşlarını dijital muhasebe süreçleri ile ilgili olumlu değerlendirmeleri ise, kamu kurum ve kuruluşlarının mesleğe bakış açılarının olumlu olduğunu, dijital muhasebenin bilgi kullanıcıları arasında bilgi paylaşımı ve kontrolde faydalı olacağını ve bilgi teknolojileri kullanılarak üniversitelerde yeni bir muhasebe eğitim modelinin oluşturulması gerektiğini düşünmeleridir. Anket sonucuna göre yükseköğretim düzeyinde yer alan programlarda muhasebe ders içeriklerinin uygulamaya yönelik revize edilmesi ile birlikte muhasebe meslek mensubu adaylarının mezun olduklarında edönüşüm uygulamalarına hâkim olarak işe başlamaları sağlanarak bu konuda başarı hızlı bir şekilde yakalanacaktır yorumu yapılabilir. 
Tablo 5: Muhasebe Meslek Mensuplarının Mesleki Kuruluşlara İlişkin (TURMOB) Dijital Muhasebe Süreçleri İle İlgili Değerlendirmeleri

\begin{tabular}{|c|c|c|c|c|c|c|}
\hline İfadeler & 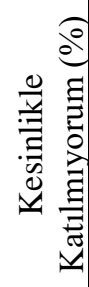 & 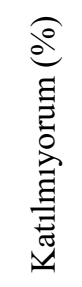 & 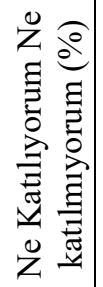 & 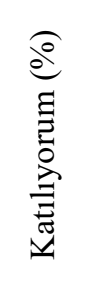 & 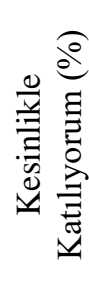 & 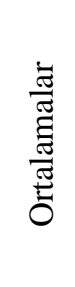 \\
\hline $\begin{array}{l}\text { 1.Meslek örgütünün e-dönüşüm sürecine yeterli katkıda bulunduğunu } \\
\text { düşünüyor musunuz? }\end{array}$ & 26,0 & 33,2 & 24,5 & 9,1 & 7,2 & 2,38 \\
\hline $\begin{array}{l}\text { 2.Meslek örgütü e-dönüşüm süreci ile ilgili sürekli eğitimler yapmakta } \\
\text { mıdır? }\end{array}$ & 22,6 & 39,4 & 23,6 & 7,7 & 6,7 & 2,37 \\
\hline $\begin{array}{l}\text { 3.Meslek örgütünün e-dönüşüm süreci ile ilgili eğitimlerinin ücretsiz } \\
\text { olması gerektiğini düşünüyor musunuz? }\end{array}$ & 6,3 & 13,5 & 19,7 & 14,4 & 46,2 & 3,81 \\
\hline $\begin{array}{l}\text { 4.Meslek örgütü e-dönüşüm süreci ile ilgili olarak sizlere bir yol haritası } \\
\text { sundu mu? }\end{array}$ & 18,8 & 30,8 & 35,6 & 10,1 & 4,8 & 2,51 \\
\hline $\begin{array}{l}\text { 5.Meslek örgütünün mesleğe girişte (staj dönemi) e-dönüşüm ile ilgili bir } \\
\text { eğitim vermesi gerektiğini düşünüyor musunuz? }\end{array}$ & 11,1 & 26,4 & 21,2 & 17,8 & 23,6 & 3,16 \\
\hline $\begin{array}{l}\text { 6.Muhasebe mesleğine girişlerin teknik ve mesleki bilgi bakımından } \\
\text { zorlaştırılması gerektiğini düşünüyor musunuz? }\end{array}$ & 12 & 16,8 & 22,6 & 20,7 & 27,9 & 3,36 \\
\hline $\begin{array}{l}\text { 7.Mesleğe girişte, kullanılan muhasebe programları ve e-belge ile ilgili ders } \\
\text { ve sinavların getirilmesi gerektiğini düşünüyor musunuz? }\end{array}$ & 3,8 & 13,9 & 18,3 & 13,9 & 50,0 & 3,92 \\
\hline $\begin{array}{l}\text { 8. Muhasebe yazılımlarının (luca,zirve, mikro vb.) ve eğitimlerinin meslek } \\
\text { örgütü tarafından ücretsiz verilmesi gerektiğini düşünüyor musunuz? }\end{array}$ & 2,9 & 5,3 & 17,8 & 12,0 & 62,0 & 4,25 \\
\hline
\end{tabular}

Tablo 5'te yer alan muhasebe meslek mensuplarının mesleki kuruluşlara ilişkin (TURMOB) dijital muhasebe süreçleri ile ilgili değerlendirmelerini içeren ifadelere verilen cevapların ortalaması 3,22'dir. Tablodan anlaşılacağı üzere katılımcıların genellikle mesleki kuruluşların faaliyetleri hakkındaki görüşlerinin olumlu olduğu ifade edilebilir. Bu kısımda yer alan ifadelerden " 8 . Muhasebe yazılımlarının (luca,zirve, mikro vb.) ve eğitimlerinin meslek örgütü tarafından ücretsiz verilmesi gerektiğini düşünüyor musunuz?" ifadesi 4,25 (4 Katılıyorum'a daha yakın) seviyesi ile en yüksek ortalamaya sahiptir. "2.Meslek örgütü e-dönüşüm süreci ile ilgili sürekli eğitimler yapmakta mıdır?" ifadesi ise 2,37 (2 Katılmıyorum'a daha yakın) seviyesi ile en düşük ortalamaya sahiptir.

Katılımcıların yüzde 59,2'si meslek örgütü TURMOB'un e-dönüşüm sürecine yeterli katkıda bulunmadığını, yüzde 62'si e-dönüşüm süreci ile ilgili konularda sürekli eğitim vermediğini ve yüzde 49,6's1 e-dönüşüm konusunda kendilerine bir yol haritası sunmadığını belirtmiştir. Bu olumsuz sonuçların ardından muhasebe meslek mensuplarının cevapları doğrultusunda meslek örgütünden beklentileri şu şekilde sıralanabilir: Meslek örgütünün e-dönüşüm süreci ile ilgili eğitimleri ücretsiz olmalı, mesleğe girişte (staj dönemi) e-dönüşüm ile ilgili eğitimler verilmeli ve muhasebe yazılımlarının (luca,zirve, mikro vb.) ve eğitimlerinin meslek örgütü tarafından ücretsiz verilmelidir. Muhasebe mesleğine giriş süreci ile ilgili önerileri ise sınavların teknik ve mesleki bilgi bakımından zorlaştırılması, kullanılan muhasebe programları ve e-belge ile ilgili ders ve sınavların getirilmesi şeklindedir.

\subsection{Hipotezlerin Test Edilmesi}

$\mathrm{H}_{1}$ : Muhasebe meslek mensuplarının demografik özelliklerine göre e-dönüşüm uygulamaları hakkındaki görüşleri farklılaşmaktadır.

Muhasebe meslek mensuplarının demografik özelliklerine göre e-dönüşüm uygulamaları hakkındaki görüşlerinin farklılaşıp farklılaşmadığının belirlenmesi amacıyla bağımsız örneklemler için t testi (Independent-Samples T Test) ve bağımsız örneklemler için tek faktörlü varyans analizi (One-Way ANOVA) uygulanmıştır. Bu analizlerde bağımlı değişken olan e-dönüşüm uygulamaları hakkındaki görüşleri; muhasebe meslek mensuplarının bilgi düzeyleri ile müşteri işletmeleri, kamu kurum ve kuruluşlarını, mesleki kuruluşlara ilişkin (TURMOB) dijital muhasebe süreçlerini değerlendirmeleri ölçeklerinde yer alan ifadelerin ortalamaları alınarak elde edilmiştir. Muhasebe meslek mensuplarının e-dönüşüm uygulamaları hakkındaki görüşleri ile 
demografik özellikler arasında yapılan analizlerinin sonuçlarına göre e-dönüşüm uygulamaları hakkındaki görüşleri ile demografik özellikler arasında anlamlı bir ilişki bulunamamıştır.

$\mathrm{H}_{2}$ : Muhasebe meslek mensuplarının bilgi düzeylerine göre e-dönüşüm uygulamaları hakkındaki görüşleri farklılaşmaktadır.

Muhasebe meslek mensuplarının bilgi düzeylerini belirlemek için kullanılan ifadelerin ortalamaları ve edönüşüm uygulamaları hakkındaki görüşlerini belirlemek için kullanılan ifadelerin ortalamaları arasındaki ilişkinin test edilmesi amacıyla korelasyon analizi kullanılmıştır.

Pearson korelasyon katsayısı, değişkenler arasında bir ilişkinin olup olmadığını varsa bu ilişkinin çok fazla mı yani kuvvetli mi ya da zayıf mı olduğu ve bir değişkene ait değerlerden biri artarken diğerinin artıyor mu ya da azalıyor mu olduğunu gösterir. Bu katsayı genellikle $r$ harfi ve $-1 \leq r \leq+1$ eşitsizliği ile gösterilir. Korelasyon katsayısı $0.7 \leq \mathrm{r} \leq 1$ aralığında ise değişkenler arasında kuvvetli, $0.3 \leq \mathrm{r} \leq 0.7$ aralığında ise değişkenler arasında orta, $0 \leq \mathrm{r} \leq 0.3$ aralığında ise değişkenler arasında zayıf seviyede bir ilişki vardır (Gürbüz ve Şahin, 2018: 262). Analizde katılımcıların bilgi düzeyleri ölçeği $(O r t=3.21, S S=0.631)$ ve e-dönüşüm uygulamaları hakkındaki görüssleri ölçeği $(O r t=3.02, S S=0.445)$ skorları arasındaki ilişki Pearson Korelasyonu ile ölçülmüştür. Bu değişkenler arasında güçlü seviyede, pozitif yönde ve anlamlı bir ilişki bulunmuştur $(r(206)=0.847, p<0.01)$.

Belirlilik katsayısının tanımı ve özellikleri "bağımlı değişkende meydana gelen değişmelerin ne kadarının bağımsız değişkendeki değişmelerle açıklanabileceğini belirlenmesi amacıyla kullanılan bir katsayıdır ve Pearson korelasyon katsayısı r'nin karesinin alınması ile hesaplanır, 0 ile 1 arasında değerler alır, $r^{2}$ sembolü ile gösterilir" şeklindedir (Ş1klar ve Özdemir, 2019: 129). Analiz sonucunda $\mathrm{r}^{2}=0,718$ olarak ölçülmüştür. Muhasebe meslek mensuplarının bilgi düzeyleri, muhasebe meslek mensuplarının e-dönüşüm uygulamaları hakkındaki görüşlerinin yüzde 71'ini açıklamaktadır.

$\mathrm{H}_{3}$ : Muhasebe meslek mensuplarının müşteri işletmeleri dijital muhasebe süreçleri ile ilgili değerlendirmelerine göre e-dönüşüm uygulamaları hakkındaki görüşleri farklılaşmaktadır.

$\mathrm{H}_{3}$ hipotezini test etmek için korelasyon analizi kullanılmıştır. Analizde katılımcıların müşteri işletmeleri dijital muhasebe süreçleri ile ilgili değerlendirmeleri ölçeği $(O r t=2.39, S S=0.760)$ ve e-dönüşüm uygulamaları hakkındaki görüsşleri ölçeği $(O r t=3.02, S S=0.445)$ skorları arasındaki ilişki Pearson Korelasyonu ile ölçülmüştür. Bu değişkenler arasında zayıf seviyede, pozitif yönde ve anlamlı bir ilişki bulunmuştur $(r(206)=0.368, p<0.01)$. Belirlilik katsayıs1 $r^{2}=0,135$ olarak ölçülmüştür. Muhasebe meslek mensuplarının e-dönüşüm uygulamaları hakkındaki görüşlerinin yüzde 13'ünü muhasebe meslek mensuplarının müşteri işletmeleri dijital muhasebe süreçleri ile ilgili değerlendirmeleri açıklar.

$\mathrm{H}_{4}$ : Muhasebe meslek mensuplarının kamu kurum ve kuruluşlarını dijital muhasebe süreçleri ile ilgili değerlendirmelerine göre e-dönüşüm uygulamaları hakkındaki görüşleri farklılaşmaktadır.

$\mathrm{H}_{4}$ hipotezini test etmek için kullanılan korelasyon analizi ile sonuçlar elde edilmiştir. Katılımcıların kamu kurum ve kuruluşlarını dijital muhasebe süreçleri ile ilgili değerlendirmeleri ölçeği ( $O r t=2.91, S S=0.593$ ) ve e-dönüşüm uygulamaları hakkındaki görüşleri ölçeği $(O r t=3.02, S S=0.445)$ skorları arasındaki ilişki Pearson Korelasyonu ile ölçülmüsştür. Bu değişsenler arasında orta seviyede, pozitif yönde ve anlamlı bir ilişki bulunmuştur $(r(206)=0.647, p<0.01)$. Belirlilik katsayısı ise $r^{2}=0,419$ olarak ölçülmüştür. Muhasebe meslek mensuplarının e-dönüşüm uygulamaları hakkındaki görüşlerinin yüzde 41'inin muhasebe meslek mensuplarının kamu kurum ve kuruluşlarını dijital muhasebe süreçleri ile ilgili değerlendirmeleri açıklar.

$\mathrm{H}_{5}$ : Muhasebe meslek mensuplarının mesleki kuruluşlara ilişkin (TURMOB) dijital muhasebe süreçleri ile ilgili değerlendirmelerine göre e-dönüşüm uygulamaları hakkındaki görüşleri farklılaşmaktadır.

$\mathrm{H}_{5}$ hipotezinde yer alan iki değişken arasındaki ilişkinin test edilmesi amacıyla korelasyon analizi kullanılmıştır. Katılımcıların mesleki kuruluşlara ilişkin (TURMOB) dijital muhasebe süreçleri ile ilgili değerlendirmeleri ölçeği $(O r t=3.22, S S=0.703)$ ve e-dönüşüm uygulamaları hakkındaki görüşleri ölçeği $(O r t$ $=3.02, S S=0.445)$ skorları arasındaki ilişki Pearson Korelasyonu ile ölçülmüştür. Bu değişkenler arasında orta seviyede, pozitif yönde ve anlamlı bir ilişki bulunmuştur $(r(206)=0.632, p<0.01)$. Analiz sonucunda belirlilik katsayısı $\mathrm{r}^{2}=0,400$ olarak ölçülmüsstür. Muhasebe meslek mensuplarının mesleki kuruluşlara ilişkin (TURMOB) dijital muhasebe süreçleri ile ilgili değerlendirmeleri, muhasebe meslek mensuplarının edönüşüm uygulamaları hakkındaki görüşlerinin yüzde 40'ını açıklamaktadır.

\section{SONUÇ}

Bilgi teknolojilerinde yaşanan gelişmeler hayatın her alanında ve her meslek grubunda değiş̧ikliklere yol açmıştır. Muhasebe alanında yaşanan teknolojik kaynaklı değişimler başta muhasebe meslek mensupları olmak üzere işletmeleri, kamu kurumlarını ve meslek örgütlerini etkilemiştir. Muhasebe alanında yaşanan bu dijitalleşme ile birlikte elektronik belge uygulamaları olarak adlandırılan e-fatura, e-defter, e-beyanname, e- 
arşiv ve e-tebligat gibi sistemler kullanılmaya başlanmıştır. Bu elektronik uygulamalar ile birlikte artık kayıtlar elle yazılarak değil elektronik ortamda tutulmaya ve saklanmaya başlamış; böylece iş gücü, kâğıt, baskı, posta, arşivleme maliyetlerinde azalma, zaman tasarrufu, evrakların kaybolma riskinde azalma, işlemlerin verimlilik ve etkinliğinin artması, işlemlerde hata riskinin azaltılması ve çalışanların motivasyonunun artması gibi sonuçlar ortaya çıkmıştır. Ayrıca muhasebede e-dönüşüm uygulamalarının ekonomide kayıt dış1lığın önlenmesi ve vergi gelirlerinin arttırılması noktasında önemli katkıları bulunmaktadır. Bu katkıların yanı sıra e-dönüşüm sürecinde muhasebe meslek mensuplarının yaşadığı bir takım sorunlar bulunmaktadır.

Bu çalışmada muhasebede yaşanan e-dönüşüm sürecinde aktif rol alan muhasebe meslek mensuplarının bu süreç hakkındaki görüşlerini ve beklentilerini belirlemek amaçlanmıştır. Hatay ilinde faaliyet gösteren ve odalar birliğine üye olan meslek mensuplarına yapılan, toplamda 438 üyeye sahip olan ve 208 üye ile uygulanan anket çalışmasının sonucu muhasebe meslek mensuplarının olumlu görüşleri, dikkat çektikleri aksaklıklar ve beklentileri şu şekildedir:

Muhasebe meslek mensupları, dijital muhasebe konusunda yeterli bilgi düzeyine sahip olduklarını ve daha önce eğitim aldıklarını ifade etmelerine rağmen dijital muhasebe konusunda hala eğitime ihtiyaç duyduklarını belirtmekte ve sürekli eğitimlerin olması gerekliliğe dikkat çekmektedirler. Ofis personeli ile ilgili olarak; dijital muhasebeye geçişten dolayı işten çıkarma yapmadıkları gibi dijital muhasebe uygulamalarını gerçekleştirebilecek ek personel istihdamına da ihtiyaç duymamışlardır. Dijital muhasebenin muhasebe mesleğinde kurumsallaşmayı artıracağına ve muhasebe mesleğinin gelecekte öneminin artacağına inanmaktadırlar. Ülke ekonomisine katkıda bulunacağına, kayıt dışılığı azaltacağına, meslekteki haksız rekabeti önlemeye katkı sağlayacağına inanmaktadırlar. Fakat ekonomide yolsuzluk ve suiistimalleri önleyemediğini, tahsilat sorununuzun çözümünde yetersiz kaldığını düşünmektedirler.

Müşteri işletmelerinin dijital muhasebe konusunda yeterli bilgiye sahip olmadıklarını, bu süreçte yaklaşımlarının olumsuz olduğunu ve fiziksel altyapılarının yetersiz olduğunu düşünmektedirler. Müşteri işletmelerin gerekli fiziksel altyapı ve bilgiye ulaşmalarının ardından dijital muhasebenin piyasa ve şirketlerin şeffaflığının ve hesap verilebilirliğini artıracağını beklemektedirler.

Muhasebe meslek mensupları, dijital muhasebeye geçiş sürecinin yeterince uzun olmadığını ve geçişte yeterli pilot uygulamalar yapılmadığını düşünmektedirler. Kamu kurumlarının farklı dijital alt yapılar kullanması, kamu kurumları personellerinin e-dönüşüm için yeterli eğitime ve bilgiye sahip olmaması, elektronik ortamda kamu kurumlarına erişimde yaşanan sıkıntı ve aksaklıklar muhasebe meslek mensuplarının bu süreçte yaşadığ 1 başlıca zorluklardır. Kamu kurum ve kuruluşlarının dijital muhasebe konusundaki yaklaşım ve uygulamalarından memnun değildirler. Ayrıca e-şifrelerin ve yetki kullanımlarından doğabilecek sorunlardan güvenlik ve gizlilik açısından endişe duymaktadırlar. Tüm bu süreç ile ilgili olarak bilgi teknolojileri kullanılarak üniversitelerde yeni bir muhasebe eğitim modelinin oluşturulması gerekliliğine dikkat çekmişlerdir.

Meslek örgütü TURMOB'un e-dönüşüm sürecine yeterince katkı sağlamadığını, dönüşüm sürecine ilişkin bir yol haritası çizmediğini ve e-dönüşüm süreci ile ilgili sürekli eğitimler yapmadığını belirtmektedirler. Muhasebe meslek mensuplarının meslek örgütünden beklentileri şu şekilde sıralanabilir: Meslek örgütünün edönüşüm süreci ile ilgili eğitimleri ücretsiz olmalı, mesleğe girişte e-dönüşüm ile ilgili eğitimler verilmeli, muhasebe yazılımları meslek örgütü tarafından ücretsiz verilmelidir. Muhasebe mesleğine giriş süreci ile ilgili önerileri ise sınavların teknik ve mesleki bilgi bakımından zorlaştırılması, kullanılan muhasebe programları ve e-belge ile ilgili ders ve sınavların getirilmesi şeklindedir.

Sonuç olarak muhasebede kullanılan teknolojik uygulamalar ile ilgili muhasebe meslek mensuplarının yanı sıra muhasebe meslek mensubu adaylarının, müşteri işletmelerin, kamu kurumlarında çalışan personellerin daha çok bilgilendirilmesi, bilinçlendirilmesi ve yönlendirilmesi önem kazanmaktadır ve böylece muhasebede e-dönüşüm uygulamalarının beklenen tüm faydaları tüm çıkar grupları için tam anlamıyla sağlayacağı düşünülmektedir. 


\section{KAYNAKLAR}

Abed, S. (2014). A review of e-accounting education for undergraduate accounting degrees. International Business Research, 7(2), 113.

Amidu, M., Effah, J., \& Abor, J. (2011). E-accounting practices among small and medium enterprises in Ghana. Journal of Management Policy and Practice, 12(4), 146-155.

Arıkan, Y. (2015). E-Uygulamalar. web: http://archive.ismmmo.org.tr/docs/YAYINLAR/kitaplar/e-uygulamalar.pdf (Erişim Tarihi, 15 Ağustos 2020).

Ay, M.H. (2006). Türkiye'de Kayıt Dışı Ekonomiyi Önlemede Bilgi Ekonomisinin Etkinliği ve Gelir İdaresinin Rolü. Selçuk Üniversitesi Karaman İ.İ.B.F. Dergisi, 11 (9), 57-82.

Çıtak, F., \& Baskan, T. D. (2020). Muhasebedeki Elektronik Gelişmelerin Muhasebe Meslek Etiğine Etkisi: Kırıkkale İlindeki Muhasebe Meslek Mensuplarının Bakış Açısı Üzerine Bir Araştırma. Muhasebe Bilim Dünyası Dergisi, $22,249-270$.

Deshmukh, A. (2006). Digital accounting: The effects of the internet and ERP on accounting. IGI Global.

Durmuş, A. F., (2018), "Opinions and Expectations of Members of Accounting Profession About Digital Accounting a Research in Malatya Province", Reading on Technology and Knowledge Management, Arad publications, s.129156.

Ermiş, K. (2006). Sayısal İmza ve Elektronik Belge Yönetimi. Bilgi Dünyası, 7(1), 121-146.

Garip, O., \& Karasioğlu, F. (2019). E-Muhasebe Uygulamaları Kapsamında Güncel Sorunlar ve Çözüm Önerileri: Karaman'da Bir Araştırma. Selçuk Üniversitesi Sosyal Bilimler Meslek Yüksekokulu Dergisi, 22(2), 433-446.

Ghaffar, A. M., Mokhtar, M. Z., Ismail, W. N. S. W., \& Othman, M. R. (2019). Determinant of e-accounting (EA) adoption among Malaysian maritime SMES. International Journal of Engineering \& Technology, 8(1.8), 102-105.

GiB. (2020). web: https://www.gib.gov.tr/ (Erişim Tarihi, 16 Ağustos 2020)

GiB. (2020a). web: https://ebelge.gib.gov.tr/efaturahakkinda.html (Erişim Tarihi, 16 Ağustos 2020)

GỉB. (2020b). web: https://ebelge.gib.gov.tr/efaturakayitlikullanicilar.html (Erişim Tarihi, 16 Ağustos 2020)

GïB. (2020c). web: https://ebelge.gib.gov.tr/eirsaliyehakkinda.html (Erişim Tarihi, 16 Ağustos 2020)

GIBB. (2020d). web: https://ebelge.gib.gov.tr/eirsaliyekayitlikullanicilar.html (Erişim Tarihi, 16 Ağustos 2020)

GIBB. (2020e). web: https://ebelge.gib.gov.tr/earsivkayitlikullanicilar.html (Erişim Tarihi, 16 Ağustos 2020)

GïB. (2020f). web: https://ebelge.gib.gov.tr/esmmhakkinda.html (Erişim Tarihi, 16 Ağustos 2020)

GïB. (2020g). web: https://ebelge.gib.gov.tr/esmmkayitlikullanicilar.html (Erişim Tarihi, 16 Ağustos 2020)

GiB. (2020h). web: https://ebelge.gib.gov.tr/emustahsilhakkinda.html (Erişim Tarihi, 16 Ağustos 2020)

GïB. (20201). web: https://ebelge.gib.gov.tr/emustahsilkayitlikullanicilar.html (Erişim Tarihi, 16 Ağustos 2020)

Gï. (2020i). web: https://ebelge.gib.gov.tr/ebilethakkinda.html (Erişim Tarihi, 16 Ağustos 2020)

GïB. (2020j). web: https://ebelge.gib.gov.tr/ebileteyolculistesiiznialanlar.html (Erişim Tarihi, 16 Ağustos 2020)

Gürbüz, S., Şahin, F. (2018). Sosyal Bilimlerde Araştırma Yöntemleri Felsefe-Yöntem-Aanaliz (5.Baskı). Ankara: Seçkin Yayıncilik

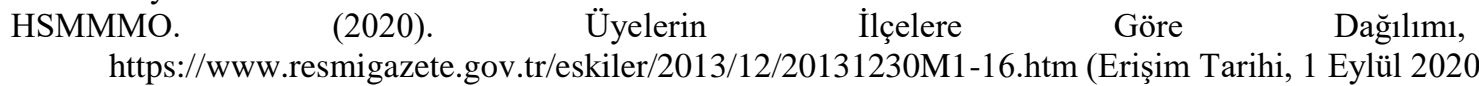

Kagermann, H., Lukas, W., \& Wahlster, W. (2011). Industry 4.0: with the internet of things on the way to the 4th industrial revolution. VDI news, 13.

Kalaycı, Ş. (Ed.). (2010). SPSS Uygulamalı Çok Değişkenli İstatistik Teknikleri (5. Baskı). Ankara: Asil Yayın

Karaer, M. (2019). Türkiye Muhasebe Sektöründeki Dijital Dönüşüm Süreci. Uluslararası Sosyal ve Beşeri Bilimler Araştırma Dergisi, 6(47), 4358-4364.

Kibar Bilginli, N. (2011). Vergi Dairesi Otomasyon Projesi (VEDOP). Dış Denetim, Temmuz-Ağustos-Eylül, 173-182.

Kulak, A. (2019). Muhasebe'de E-Dönüşüm. İnönü Üniversitesi, Sosyal Bilimler Enstitüsü, Yüksek Lisans Tezi.

Maliye Bakanlığı. (2010). Vergi Usul Kanunu Genel Tebliği (Sıra No: 397). Ankara.

Noronha, M. R., \& Kulkarni, A. R. (2012). E-Accounting in India. Indian Journal of Accounting, 42(2), 1-10.

Öztürk, M. S., \& Çarıkçı, O. (2019). Elektronik Muhasebe Uygulamaları Kapsamında Geleceğin Muhasebecileri Üzerine Bir Araştırma. Avrasya Uluslararası Araştırmalar Dergisi, 7(16), 1007-1026.

Popkova, E. G., Ragulina, Y. V., \& Bogoviz, A. V. (Eds.). (2019). Industry 4.0: Industrial revolution of the 21st century (p. 253). Springer.

Relhan, A. (2013). E-accounting practices of SMEs in India. International Journal of Technical Research, 2(1), 1-10.

Şıklar, E., Özdemir, A. (Ed.). (2019). İstatistik II. Eskişehir: T.C. Anadolu Üniversitesi Yayını

Velankar, N., Gupta, R. C., \& Garud, U. (2013). E-Accounting practices among SMEs: a study of MP Region. Journal of Management Value and Ethics, 3, 94-106.

213 No'lu VUK Genel Tebliği. (2010). web: https://www.mevzuat.gov.tr/MevzuatMetin/1.4.213.pdf (Erişim Tarihi, 16 Ağustos 2020)

397 No'lu VUK Genel Tebliği. (2010). web: https://www.resmigazete.gov.tr/eskiler/2010/03/20100305-16.htm (Erişim Tarihi, 16 Ağustos 2020)

433 No'lu VUK Genel Tebliği. (2013). web: https://www.resmigazete.gov.tr/eskiler/2013/12/20131230M1-16.htm (Erişim Tarihi, 16 Ağustos 2020) 